\title{
Muscle Satellite Cells: Exploring the Basic Biology to Rule Them
}

\author{
Camila F. Almeida, Stephanie A. Fernandes, Antonio F. Ribeiro Junior, \\ Oswaldo Keith Okamoto, and Mariz Vainzof
}

Human Genome and Stem Cell Research Center, IBUSP, Rua do Matão 106, Cidade Universitária, 5508-900 São Paulo, SP, Brazil

Correspondence should be addressed to Mariz Vainzof; mvainzof@usp.br

Received 9 December 2015; Accepted 24 January 2016

Academic Editor: Silvia Brunelli

Copyright (C) 2016 Camila F. Almeida et al. This is an open access article distributed under the Creative Commons Attribution License, which permits unrestricted use, distribution, and reproduction in any medium, provided the original work is properly cited.

\begin{abstract}
Adult skeletal muscle is a postmitotic tissue with an enormous capacity to regenerate upon injury. This is accomplished by resident stem cells, named satellite cells, which were identified more than 50 years ago. Since their discovery, many researchers have been concentrating efforts to answer questions about their origin and role in muscle development, the way they contribute to muscle regeneration, and their potential to cell-based therapies. Satellite cells are maintained in a quiescent state and upon requirement are activated, proliferating, and fusing with other cells to form or repair myofibers. In addition, they are able to self-renew and replenish the stem pool. Every phase of satellite cell activity is highly regulated and orchestrated by many molecules and signaling pathways; the elucidation of players and mechanisms involved in satellite cell biology is of extreme importance, being the first step to expose the crucial points that could be modulated to extract the optimal response from these cells in therapeutic strategies. Here, we review the basic aspects about satellite cells biology and briefly discuss recent findings about therapeutic attempts, trying to raise questions about how basic biology could provide a solid scaffold to more successful use of these cells in clinics.
\end{abstract}

\section{Introduction}

Skeletal muscle is a postmitotic tissue that has a high regenerative potential. This feature is mainly due to satellite cells (SCs), which form a reservoir of precursor cells that are responsible for its after-birth growth and also for the response to injuries, either by exercise or by disease [1]. Their amounts in the adult muscle could vary between 3 and $11 \%$ of the myonuclei, depending upon which species are being analyzed. In mice, the amount of SCs drops from $32 \%$ in neonates to $5 \%$ in adults $[2,3]$. These cells are strictly associated with the sarcolemma, residing between the membrane and the basal lamina [4], becoming associated with the muscle fiber before the formation of its surrounding lamina [3].

These cells are easily identified by their location and morphology. However, efficient ways to obtain these cells involve the use of several markers that characterize this cell type, the transcription factor Pax7 being the most remarkable one [5]. Even though they are well studied and recognized, the SC population is highly heterogeneous [6].
Although quiescent in normal adult muscles, these cells can be activated by specific signals when a muscle injury occurs. Upon activation these cells undergo asymmetric division, by which they could form cells that either are capable of self-renewing or can enter the myogenic pathway and differentiate to restore the muscle [7-9]. Nonetheless, in diseases characterized by relentless degeneration, like muscular dystrophies, the satellite cells are constantly activated, which eventually leads to depletion of the SC pool and consequent failure of the regeneration process [10]. Currently, there is no effective treatment for muscle degenerative diseases; thus, many researchers are focusing on stem cell-based therapies. However, to date, most attempts are limited to animal models and former clinical trials have failed.

In this review, we summarize recent findings about the basic biology of muscle-specific stem cells and discuss possible new avenues to more effective and feasible therapeutic approaches to muscle wasting disorders, mainly muscular dystrophies. 


\section{Origin of Satellite Cells in the Muscle Development}

In the embryo, mesoderm structures called somites are formed and skeletal muscles are derived from a specific region, the dermomyotome [11]. In this step the first muscle fibers are formed and additional fibers are added afterwards using the former as a template $[12,13]$. In the final period of embryogenesis, muscle progenitors start to proliferate vastly until they arrive in a state in which the number of nuclei is maintained and the synthesis of myofibrillar protein hits its peak [14]. The muscle then reaches a mature state with its residing progenitor cells, the SCs, acquiring a quiescent state in this tissue [11].

In somites, the high concentrations of FGF and Wnt in the caudal area lead to formation of mesenchymal cells in an undifferentiated state and this pathway also involves the control by Notch [15]. Then, the most dorsal part forms the dermomyotome, which will give rise to the majority of skeletal muscles. Cells of this compartment have high expression of the factors Pax 3 and Pax7 and a low expression of the myogenic regulator Myf5 [16-18]. Afterwards, the maturation of a dermomyotome piece will form the myotome, which is characterized by the expression of MyoD and Myf5 [18-20]. Muscle progenitors subsequently intercalate into the primary myotome, and these will originate a fraction of the SCs that resides within the postnatal skeletal muscle [21-24].

SCs are known to participate in adult muscle regeneration, and many similarities have been described between this process and the embryonic myogenesis, as relating SCs to progenitors of somatic origin [21-23, 25] (Figure 1(a)). It is also important to notice that the cells involved in the adult regeneration process are under the same genetic hierarchy involved in embryonic myogenesis, with the same genes participating in their regulation [26] (Figure 1(b)). The major distinction between myogenesis in the embryo and regeneration is that the latter requires a scaffolding that will work as a template [27].

A number of data also indicate that there are specific SCs that undergo asymmetric division, generating committed cells dedicated to the regeneration process, but also producing new SCs that are able to replenish the muscle stem cells pool [11].

Adult myogenic cells are derived mainly from SCs during late fetal development. However, there has been evidence of other adult stem cell populations that can also be involved in regeneration [12]. Nonetheless, it is remarkable that even though these other stem cells exist and have myogenic potential, experiments that deplete Pax7-satellite cells show that no other stem cell type is able to replenish the SC pool nor act in regeneration after injury, highlighting the unique importance of SCs [28].

\section{Satellite Cell Markers}

Satellite cells can be identified by the expression of several markers, with special attention to Pax7, which is considered the main defining factor for this cell type [5]. This marker has been correlated with the maintenance of an undifferentiated state, being an important factor for self-renewal in these cells [29]. In addition to Pax7, another protein from the paired domain transcription factor family might be expressed, Pax3, which is also important in the initial steps of muscle formation and is involved in the transcription of another marker, the tyrosine receptor kinase c-Met [30-32]. Interestingly, in the knockout mouse for Pax7, some SCs can be found, indicating that Pax 3 alone could play a similar role $[30,33]$. Conversely, other results suggest that Pax 3 is not able to compensate for the Pax7 function [32]. In addition, the presence of Pax3 SCs is dependent on the muscle type [30].

Besides the Pax protein family, many other markers can be used to identify SCs such as the myogenic regulatory factor Myf5 [31, 34]; homeobox transcription factor Barx2, which is coexpressed with Pax7 and is a regulator of muscle growth, maintenance, and regeneration [35]; cell adhesion protein M-cadherin, which is known to be coexpressed with c-Met $[31,36]$; cell surface attachment receptor 7-integrin [37, 38]; cluster of differentiation protein (CD34) that is expressed in quiescent SCs [34]; transmembrane heparan sulfate proteoglycans syndecan-3 and syndecan-4 [39]; chemokine receptor CXCR4 [40]; caveolae-forming protein caveolin-1 [38, 41]; calcitonin receptor, which was described as related to the quiescent state [38, 42]; vascular cell adhesion protein 1 VCAM-1 [43]; neural cell adhesion molecule 1 NCAM-1 [44, 45]; and nuclear envelop proteins lamin $\mathrm{A} / \mathrm{C}$ and emerin [38]. However, these individual proteins are not exclusively expressed in SCs, meaning that only their simultaneous coexpression has been useful in identifying this cell type. Although other markers have been proposed to identify SCs, the ones cited above, and indicated in Figure 2, are the most commonly studied. Table 1 is presenting examples of antibodies for immunofluorescence referred to in the literature. Different antibodies can be used according to the adopted methodology (western blotting, flow cytometry, etc.).

\section{Heterogeneity in the Satellite Cell Population}

Even though the identification of satellite cells is based on marker expression and morphological analysis, it has been suggested that these cells comprise a heterogeneous population of precursor cells [33]. It has also been reported that these cells can be prone to be committed either to the muscle lineage or to the self-renewal pathway, which is also an evidence of its heterogeneity [44, 46, 47]. The expression of the markers cited in the previous section, although well established in the literature, can be variable in this cell population, being another indication that this cell population can be heterogeneous, even though cells maintain their myogenic potential.

For instance, the expression of the marker Myf5 has been reported to be absent in $\sim 10 \%$ of the SC population, and the cells identified as Pax7+/Myf5- contributed to their reservoir in contrast with Pax $7+/$ Myf5 + cells that were committed to differentiation [48]. Studies also showed that activated cells 


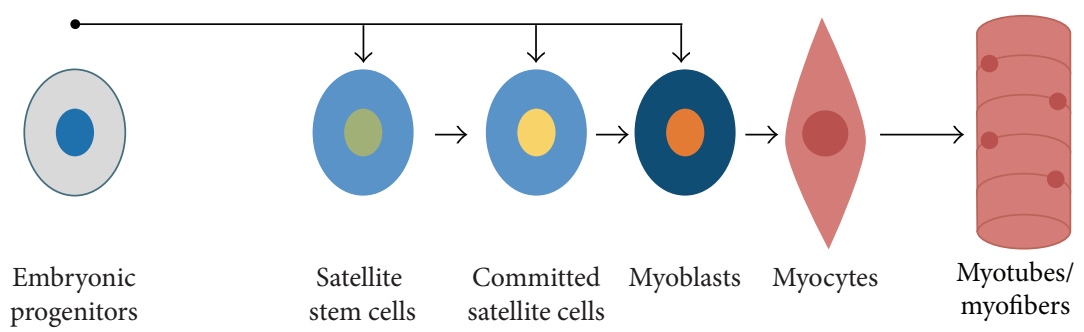

(a)

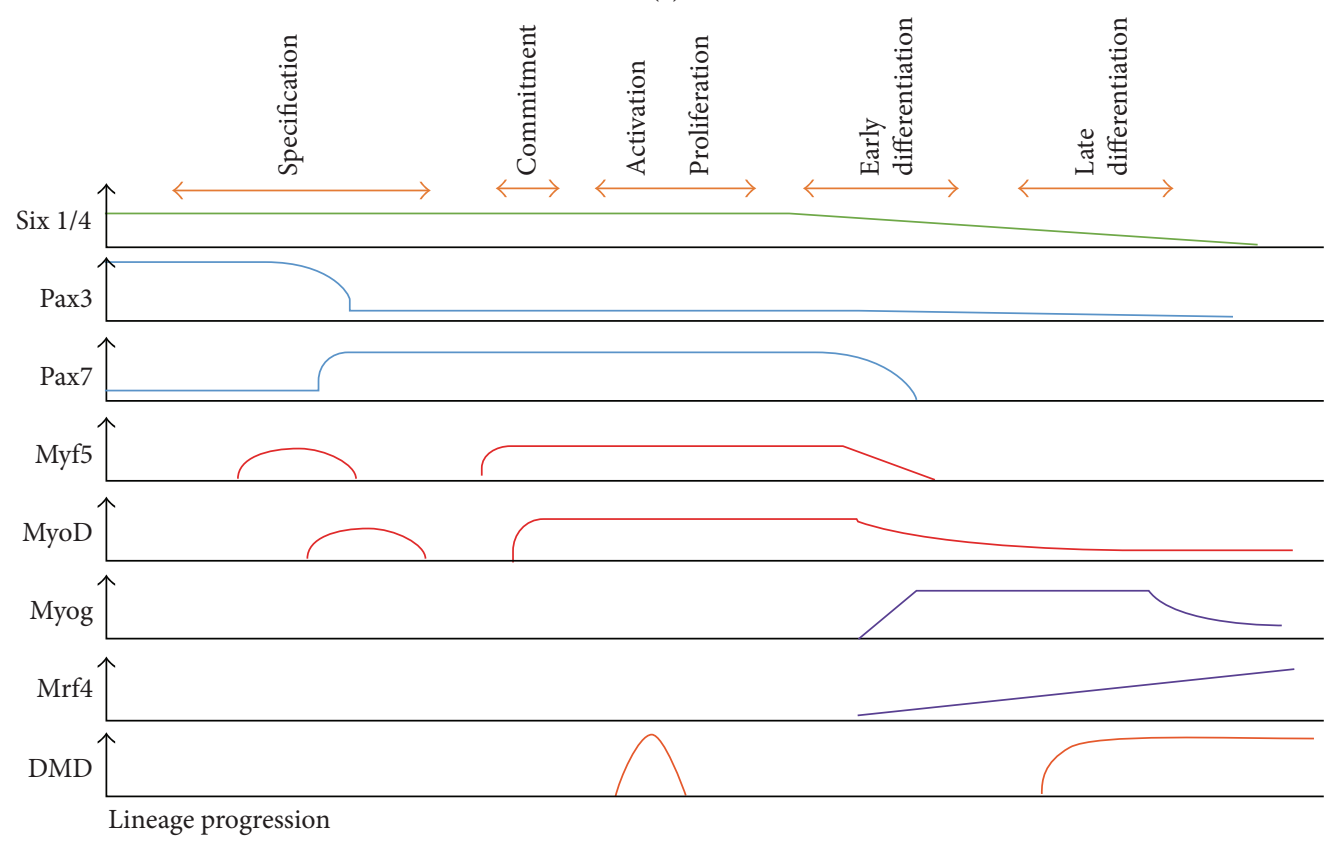

(b)

FIGURE 1: Cell hierarchy during development and adult myogenesis. (a) During development, an embryonic progenitor directly originates satellite stem cells, committed satellite cells, and myoblasts, which afterwards form a mature fiber. Some of them remain as satellite cells forming a heterogeneous population of stem and committed cells. In adult myogenesis, satellite cells can form myoblasts that will go through a similar process observed in development. (b) Genetic hierarchy of transcription factors involved in myogenesis. Six 1/4, Pax3, and Pax7 are the most important factors to muscle lineage specification, while Myf5 and MyoD prime cells to the myogenic program. Myog and Mrf4 control the myocytes fusion and the formation of myotubes. Dystrophin expression was recently also described in satellite cells. Adapted from Bentzinger et al., 2012 [11].

expressing low levels of Pax7 were more committed to differentiation, whereas high levels of Pax7 were related to cells less prone to differentiate and that had more undifferentiated characteristics [49]. Experiments with histone 2B labeling also demonstrated that there are SCs that retain or lose this mark and that the former is able to self-renew and the cells that lose the mark are restricted to differentiation [50].

Differences were also observed in the proliferation rate of SCs, as slow and fast dividing cells coexist [51]. The slow ones are capable of long-term self-renewal, whereas fast dividing cells compromise themselves with the myogenic lineage without producing self-renewing progeny [52]. In this sense, subpopulations that are considered committed to the myogenic lineage could participate in the regeneration of an injured muscle before the ones that are still in the more progenitor state and so would take a longer time to be involved in this process [53]. This scenario is consistent with a stem cell to progenitor cell hierarchy.
As it is known that muscles within the body are distinct between themselves, it has been seen that SCs also present heterogeneity based on the muscle they are located within, which may correlate to their distinct embryonic origin [6, 54]. This is consistent with the previous results observed by Buckingham et al. and Relaix et al. that shows that the expression of Pax3 by SCs is muscle-dependent [30, 32]. As knowledge increased, studies were done to determine whether the heterogeneity of SCs in muscle was due to the muscle environment or internal programming, and the outcomes of distinct researches showed that there is evidence for both $[55,56]$.

Differences in SCs were also found when considering the extrafusal fibers and their categorization into fast and slow fibers regarding proliferation rate and differentiation potential. Remarkably, the SCs could differentiate into exclusive fast fibers when they came from a fast muscle and into fast or slow fibers when they are derived from a slow muscle [57-59]. 
TABLE 1: Examples of antibodies used to identify satellite cells by immunofluorescence. $\mathrm{Hu}=$ human; Mo = mouse.

\begin{tabular}{llll}
\hline Protein & Company/catalogue number & Reacts with & Reference \\
\hline Pax7 & Hybridoma Bank (DSHB) & Hu/Mo & Dumont et al., 2015 [147] \\
\hline $\begin{array}{l}\text { MyoD } \\
\text { CXCR4 }\end{array}$ & $\begin{array}{l}\text { Santa Cruz Biotechnology/C-20 } \\
\text { Abcam/not mentioned }\end{array}$ & $\mathrm{Hu} / \mathrm{Mo}$ & Cerletti et al., 2008 [167] \\
\hline Barx2 & Santa Cruz Biotechnology/sc-9128 & Mu/Mo & Meech et al., 2012 [35] \\
\hline Syndecans 3 and 4 & Non-commercial antibody & $\mathrm{Hu} / \mathrm{Mo}$ & Cornelison et al., 2001 [39] \\
\hline M-cadherin & BD Biosciences/611101 & $\mathrm{Mo}$ & Marti et al., 2013 [168] \\
\hline Caveolin-1 & Santa Cruz Biotechnology/sc-894 & $\mathrm{Mo}$ & Gnocchi et al., 2009 [38] \\
\hline CD56/NCAM & BD Biosciences/347740 & $\mathrm{Hu} / \mathrm{Mo}$ & Lindström et al., 2015 [169] \\
\hline Pax3 & Hybridoma Bank (DSHB) & $\mathrm{Hu}$ & Kirkpatrick et al., 2010 [170] \\
\hline c-Met & Novocastra Laboratories/CMET-S & $\mathrm{Mo}$ & Lindström et al., 2010 [171] \\
\hline CD34 & PharMingen/clone RAM34 & $\mathrm{Hu}$ & Beauchamp et al., 2000 [34] \\
\hline Myf5 & Santa Cruz Biotechnology & $\mathrm{Mo}$ & Günther et al., 2013 [172] \\
\hline Calcitonin receptor & AbD Serotec/AHP635 & $\mathrm{Hu} / \mathrm{Mo}$ & Yamaguchi et al., 2015 [173] \\
\hline $\begin{array}{l}\text { Desmin } \\
\text { Lamin A/C }\end{array}$ & DAKO/clone D33 & $\mathrm{Hu} / \mathrm{Mo}$ & Frock et al., 2006 [174] \\
\hline
\end{tabular}

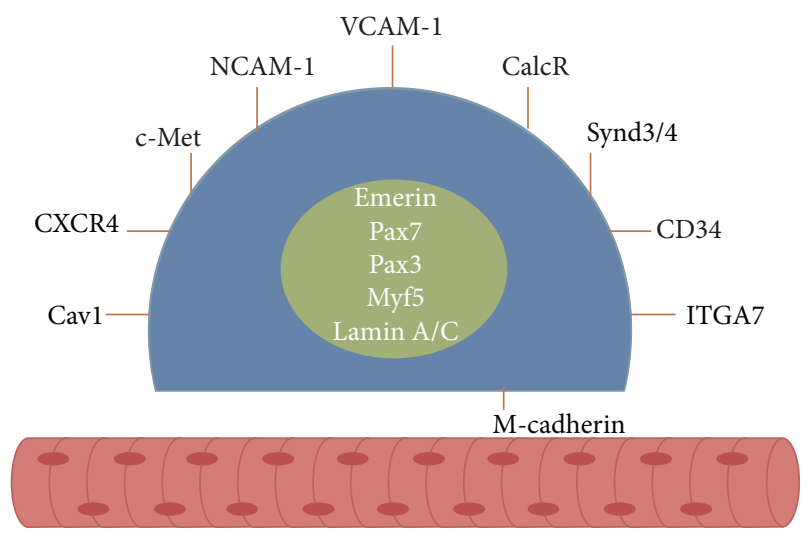

FIGURE 2: Principal satellite cell markers currently used for their identification.

As observed previously, the phenotype after differentiation can either be dependent on the intrinsic programming that is related to the fiber type or can be under influence of the environment, that is, the muscle fiber with whom the cell interacts $[6,60]$. As for intrafusal fibers, SCs in this compartment are known to be more plastic and directed to a specific phenotype by foreign innervation stimulation $[61,62]$.

Morphological differences translated as round and thick cells were also observed in the SC population and they were associated with distinct myogenic potential [63], the thick ones being more prone to differentiation. Functionally, there are observations that suggest two subpopulations of SCs, one that is committed to muscle growth, whose cell number declines with age and is present in a larger amount in males, and another subpopulation related to muscle regeneration after an injury, whose cell amount is relatively maintained during aging and is not gender related [64].

The heterogeneity may also result from the distinct niche in which these cells are located, as has been observed in the aging process, where cells may escape quiescence and lose their capacity of self-renewal [65-67]. An important component of the muscle niche that acts directly in proliferation and differentiation of satellite cells is the fibro/adipogenic precursors, and it is known that they act positively in young $D m d^{m d x}$ mice, the model for Duchenne Muscular Dystrophy, but repress the formation of myotubes in old ones, indicating that the process of aging has direct implications in satellite cells [68]. Other factors such as Notch and Wnt are also involved in this nonautonomous process of SCs aging [67, 69]. In addition, intrinsic changes in cells are also observed in the aging process, such as in geriatric SCs that lose the reversible quiescence and enter in a presenescence that cannot be reversed and that in an injured muscle fail to start the regenerative process and enter in a full senescence state [70]. It was also shown that intrinsic cell factors also lead to the loss of self-renewal with the involvement of the MAPK pathway $[71,72]$. It is important to distinguish between autonomous and cell nonautonomous factors that interfere with SCs in aging, since the nonautonomous ones, such as the niche, can be corrected with a youthful environment [73], a fact that cannot be corrected when the factor is intrinsic to the cell [70].

This heterogeneity in the stem cell population in muscle has been complicating the identification, function, and naming of these cells. There has been in the literature a description of other types of cells with high myogenic capacity and directly related to muscle regeneration, called muscle derived stem cells that express distinct markers [74]. Nonetheless, it is important to notice that there have been subsequent results indicating that, without SCs, no other cell types have the capacity to regenerate muscle [28]. This may be either because the other cell types studied did not include the specific population described by Qu-Petersen and colleagues [74], or that the activity of other cell types has a requirement for use in conjunction with SCs or with the major SC factor Pax7 [75].

Additionally, diverse muscle derived stem cell (MDSC) populations had been identified. These populations include 
myogenic progenitor cells characterized as CD56+, CD34-, CD144-, CD45-, and CD146-; CD56+, CD34+, CD144+, CD45-, and CD146- mio-endothelial cells; CD56-, CD34-, CD144-, CD45-, and CD146+ perivascular progenitor cells; and a muscle derived side population which has similar features to bone marrow stem cells [76]. Based on adhesion and proliferative properties, $\mathrm{Qu}$-Petersen and colleagues [74] isolated three cell populations derived from muscle. Two of these populations, EP (early preplate) and LP (late preplate), represent the satellite cells; the third one, which also adheres lately, is named MDSC and presents characteristics usually associated with noncommitted progenitor cells. The EP population represents the majority of the cells obtained from muscle digestion and differentiates into myotubes. However, EP cells have a limited regenerative potential. The LP population accounts for about $1 \%$ of satellite cells, but it has low rates of proliferation and differentiation. Conversely, MDSC showed a better self-renewal ability and sustained proliferation and are multipotent. Thus, the MDSC would be less committed cells and more promising for therapies in comparison to satellite cells [74].

Other cell types, such as bone marrow mesenchymal stem cells [77-81], adipose derived mesenchymal stem cells [8284], CD133+ cells [85-87], pericytes/mesoangioblasts [88, 89], and side population cells [90, 91], were described as being able to participate in myotube formation as well as replenishing the satellite pool. These cells are not initially committed to muscle and may not express the classical satellite cell marker, Pax7. However, they are capable of contributing to muscle regeneration when fusing with myogenic cells and, additionally, they may be able to turn into Pax7 expressing cells originating new SCs, which is a fact that may strongly contribute to the heterogeneity observed in this population. It is also important to notice that evidence has been found that myogenic cells are formed by fusion [78, 92-94] or transdifferentiation, in which cells develop into intrinsically myogenic ones [95-97], and the heterogeneity would rise by the contribution of both cells that participate in the fusion process or by one cell initially not committed to muscle becoming myogenic. Furthermore, other cell types may be involved in assisting muscle regeneration sending signals that direct differentiation of SCs, such as fibro/adipogenic precursors [98-100]. It is clear then that whether one cell type turns into muscle by fusion or transdifferentiation or that the precursor itself receives signals that direct their proliferation and differentiation, the final outcome is that all these factors contribute to the myogenic population being heterogeneous.

\section{Satellite Cells Can Undergo Multilineage Differentiation}

Besides their myogenic potential, it has been described in the literature that these cells can undergo osteogenic and adipogenic differentiation, for example. This highlights their properties as a stem cell that is able to differentiate within the mesenchymal lineage [101-104].

Studies in rat showed that the heterogeneity in the proliferation rate correlates with the differentiation potential, with high proliferative clones being able to differentiate into adipocytes [105]. Morphological heterogeneity was also related to distinct potential, with thick cells also being able to undergo osteogenic differentiation [63]. Heterogeneity also in the CD34 expression was correlated with distinct potential to go through the adipogenic pathway, and only cells that expressed this marker were able to undergo adipogenic differentiation [106].

Additionally, in aged mice, it was observed that SCs tend to go to the fibrogenic lineage instead of maintaining their myogenic potential, which may contribute to the greater fibrosis observed in old mice [69].

\section{The Balance between Quiescence and Activation}

Skeletal muscle regeneration follows a series of steps that recapitulates the phases of development. First, muscle progenitor cells must exit the state of quiescence and become active and proliferate. Asymmetric divisions are important to provide daughter cells committed to the myogenic program (myoblasts) and also daughter cells that return to quiescent state in order to replenish the stem cell pool. After proliferation, myoblasts differentiate and fuse to form myotubes, which fuse with each other or to a previous fiber to repair it. Finally, the myofibers grow and maturate.

6.1. Quiescence Mechanisms. As other types of adult stem cells, SCs are quiescent until they are activated when there is a muscle injury. Maintenance of quiescence is crucial to preserve the SC pool and it is controlled by different molecular mechanisms, with participation of many genes and regulatory pathways. Microarray studies showed that more than 500 genes are overexpressed in quiescent SCs in comparison with proliferating myoblasts [42]. Negative regulators of cell cycle are among these genes. Despite the fact that all the players and mechanisms of SCs' homeostasis are not being fully understood, many efforts have been employed in order to depict them (Figure 3).

The Notch signaling was implicated in SC quiescence maintenance, as well as proliferation and differentiation regulation, in various studies [107-111]. Indeed, Notch signaling was established as the first quiescence regulator in adult stem cells because an interruption in Notch activity favors spontaneous cell differentiation, without the entry in the $S$ phase [110]. The highest activity of Notch signaling is seen in quiescent SCs and it is progressively reduced as the cell progresses through myogenic differentiation. Interestingly, Notch signaling prolonged blockage does not prevent cells from proliferating but leads to depletion of SC, demonstrating that it is necessary for self-renewal [110]. A similar study showed related results about the loss of Notch signaling by RBP-J deletion. The absence of Notch signaling has at least three main effects: failure of quiescence maintenance; loss of the ability to self-renew; and spontaneous differentiation, without a phase of proliferation [108].

The FOXO family of transcription factors regulates stem cell pools in adult tissues. The levels of Foxo3 transcript 


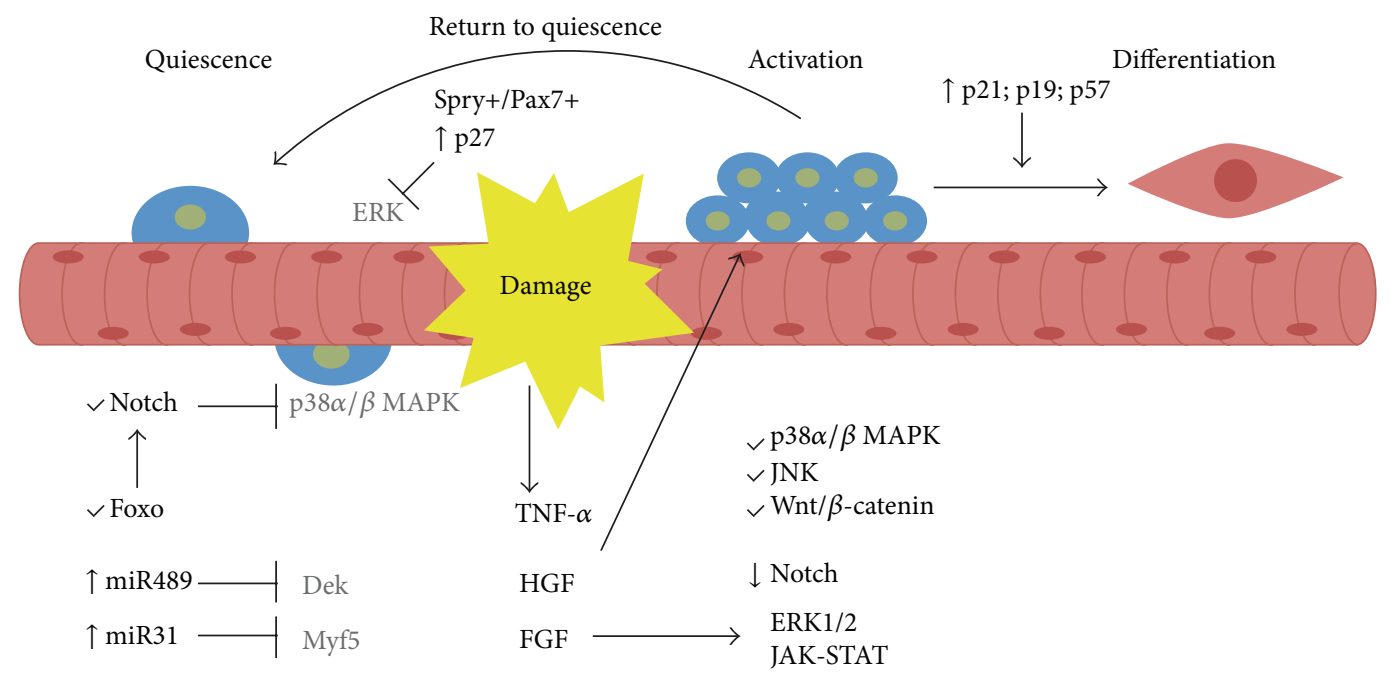

FIGURE 3: Quiescence and activation control. Notch signaling is one of the main pathways controlling quiescence. Foxo transcription factors regulate Notch receptors expression facilitating this pathway's activity. MicroRNAs target cell cycle genes and myogenic regulators. Upon injury, signaling molecules are released and pathways related to cell cycle progression are turned on. After some rounds of division, some cells return to quiescence whereas the others exit cell cycle and proceed into the myogenic program, differentiate, and repair the damage.

and protein are higher in quiescent SCs than in activated ones. The ablation of Foxo3 gene specifically in SCs showed that this transcription factor is important for SC return to quiescence and self-renew. FOXO3 negative cells are more proliferative and differentiate more rapidly, while Foxo3 overexpression suppresses cell cycle entry and represses terminal differentiation [112]. This work also links FOXO3 to Notch signaling: FOXO3 regulates NOTCH1 and $\mathrm{NOTCH} 3$ receptor expression, activating Notch signaling, and thus promotes quiescence in SCs [112].

MicroRNAs are significant players in gene expression regulation, including genes related to stem cell functions; and their activity in SCs regulation has been recently explored. It was demonstrated that miR-489 is highly expressed in quiescent SCs and is downregulated as they become activated. A target of miR-489 is Dek, an oncogene, whose both mRNA and protein levels are higher in activated SCs than in quiescent SCs. In SCs, Dek promotes proliferation after activation; Dek-positive cells are committed to myogenic differentiation and Dek-negative cells are self-renewing [113]. Another miRNA involved in SCs quiescence is miR-31. Although the majority of SCs in adult tissue have the Myf5 gene activated [48], they do not necessarily differentiate, which implies that a mechanism must exist to prevent Myf5 mRNA translation before the appropriated moment. This repression is accomplished by miR-31 that has a higher expression in quiescent SCs; it targets Myf5 mRNA and then sequesters it in mRNP granules. Upon activation, miR-31 levels decrease and Myf5 mRNA is released to translation [114].

SCs quiescence is also established by mRNA decay. Hausburg and colleagues showed that Myod transcript is driven to mRNA decay, preventing the SC to proceed in the myogenic program. This is achieved by the action of the protein tristetraprolin (TTP) that binds to mRNA, preventing it to be translated and, in addition, regulating its decay [115].
All these posttranscriptional regulation mechanisms seem to be somewhat redundant and they seem to act in a subpopulation-specific manner; however, more studies are necessary to clarify all the mechanisms involved in quiescence maintenance and to define whether they are common to all SCs.

6.2. Activation and Proliferation Mechanisms. When the muscle suffers an injury, the SCs must be activated, starting to proliferate and differentiate to repair and/or form new muscle fibers. SC activation is a transient process regulated at different levels. As Notch inhibits p38 $\alpha / \beta$ MAPK signaling pathway in quiescent stage [116], this is the first pathway to be activated [117], resulting in the expression of Myod and consequent cell cycle entry. The damaged fibers release many growth factors that induce the activation of signaling pathways related to cell cycle, like TNF- $\alpha$, HGF, and FGF [118120]. The transition from G1 to $S$ phase is achieved by activation of ERK1/2 pathway by Fgf2 [121]. Another MAPK signaling pathway involved in SC cell cycle progression is JNK [122].

The intense cell proliferation is important to muscle repair, but it has to be limited and the fate of each daughter cell must be determined-terminally differentiate or return to quiescence. Wnt $/ \beta$-catenin signaling is temporally activated during regeneration but later downregulated to limit the regenerative response [123]. Wnt/ $\beta$-catenin signaling is also involved in the promotion of myogenic differentiation. The treatment of SCs with Wnt3a promotes cell cycle arrest, myogenin activation, and follistatin expression, promoting myoblast fusion and terminal differentiation [124].

The JAK-STAT signaling is another player in the regulation of SC function, especially in the aged muscle, whereby Stat3 activation interferes in MyoD to promote myoblast differentiation [125]. JAK-STAT signaling increases progressively with age or disease. Jak2 and Stat3 transient inhibition 
in aged and dystrophic muscle enhances SC expansion and better muscle regeneration [126, 127].

6.3. Cell Cycle Exit. To exit the cell cycle, upregulation of inhibitors of cyclin-dependent kinases is required. The return to quiescence requires $\mathrm{p} 27^{\mathrm{kip} 1}$, whereas the progression through myogenesis requires the upregulation of $\mathrm{p} 21^{\mathrm{Cip} 1}$, p19 ${ }^{\text {Arf }}$, and p57 [50, 128, 129]. Sproutyl (Spry1) is a receptor tyrosine kinase signaling inhibitor expressed in $\mathrm{Pax}^{+}$quiescent cells, but downregulated in proliferating myoblasts. When Pax $7^{+}$cells return to quiescence Spryl is induced again, promoting cell cycle exit by inhibiting ERK pathway [130].

6.4. Asymmetric Divisions and Self-Renewal. The daughter cells asymmetry, that is, segregation of different determinant factors, will determine whether they differentiate or selfrenew. The myogenic determinant factors Myf5, MyoD, and Myog have asymmetric expression in the daughter cells [48, 131, 132]. MyoD is distributed to committed Pax7-cells and the Pax+/MyoD- cells are self-renewing [133]. For Myog, the same is observed: the myogenic lineage is Pax7-/Myog+ and reservoir cells are Pax7+/Myog- [134]. The distribution of DNA template is also asymmetric: the old template goes to the daughter cell expressing Pax7, the reservoir cell, and the new DNA template to the one expressing Myog [134].

In Myf5-negative SCs, those compromised with renovation of the stem cell pool, the Notch3 receptor is enriched, whereas Myf5-positive cells receive the Notch ligand Deltal [48]; in Myog-positive cells there is also the presence of Numb, a Notch antagonist [107]. All these findings are related to the role of Notch signaling in maintenance of quiescence, as discussed above.

\section{Satellite Cells in the Context of the Muscular Dystrophies}

Different hypothesis and mechanisms are proposed to explain the muscular degeneration that occurs in patients bearing mutations in a wide number of genes important to muscle structure and function $[135,136]$. As the dystrophic muscle is persistently injured, the regenerative process is consistently activated, recruiting satellite cells at higher rates than in normal tissue. Nevertheless, in dystrophic muscle, the regeneration is not complete and there is a progressive replacement of muscle by fibrofatty tissue. Thus, the ability of stem cells to repair the muscle is not sufficient to compensate for degeneration. Three scenarios are proposed to explain this limited regenerative capacity [135].

First, the repetitive cycles of replication would lead SCs to senescence, due to telomere shortening. The presence of shortened telomeres was observed in DMD (Duchenne Muscular Dystrophy) and LGMD2C (limb-girdle muscular dystrophy type 2 C) patients $[137,138]$ and in $D m d^{m d x}$ mice [139]. $D m d^{m d x}$ mice lacking telomerase activity develop a phenotype more faithful to muscular dystrophy in humans, including a worsening with aging [140]. However this is controversial, as another study could not detect a significant telomere shortening [141].
Second, the differentiation could not be adequate. Early studies showed that myoblasts from DMD patients delay to fuse and present an abnormal differentiation [142, 143]. In some types of muscular dystrophy, the mutated gene is not expressed in SCs and thus does not influence directly on their function [144]. However, there is also evidence that the primary mutation itself can impair the SC function by reducing its number and causing premature senescence, implicating SC as directly involved in the disease mechanism [145]. Alterations in signaling pathways are also underlying the regenerative potential of SCs. In a knockin conditional mouse in which Notch signaling is blocked in SCs, the muscle develops a typical dystrophic phenotype with impaired regeneration [146]. The SCs of this mouse showed reduced activation and proliferation, but enhanced differentiation, corroborating the previous studies about the role of Notch signaling in quiescence maintenance [146]. In $D m d^{m d x}$ mouse, the Notch signaling is attenuated, which diminishes SCs self-renewal; and the constitutive activation of Notch recovered the self-renewal capacity, but this is not sufficient to improve regeneration, probably because of MyoD and myogenin inhibition [111].

Dystrophin is expressed in differentiated myofibers, but not in proliferating myoblasts; thus it was believed that it was not expressed in satellite cells either. However, a recently published paper elegantly showed that dystrophin is indeed expressed by satellite cells and that it plays an essential role in the regulation of their polarity and asymmetric division. In the absence of dystrophin, there is a reduction in the number of asymmetric divisions and more abnormal divisions, which lead to a decrease in the quantity of myogenic progenitors and thus a failure in muscle regeneration [147]. This work adds a major role for satellite cells dysfunction in the pathophysiology of DMD, which has direct implications for therapies. Third, the dystrophic niche is not favorable for regeneration. In the dystroglycanopathy mouse model Large $^{\text {myd }}$, an increased number of SCs were found in freshly isolated single fibers, related to control mouse [148]. As long as SCs remained attached to the fibers, their proliferative capacity was seen to be reduced, but after total isolation they proliferated and differentiated at levels comparable to normal control, indicating an important role of the niche to stem cell function [148]. In this mouse model, the basal lamina composed by an excess of fibronectin and collagen acts as an obstacle to proper SC proliferation. This work contradicts a former one which suggested that as SC also expresses dystroglycan, the glycosylation defect would also affect its function, impairing regeneration [149]. Even though a recent publication reinforces that the regenerative capacity is not affected in muscles with glycosylation deficiency, the inability to overcome the degeneration is more related to the depletion of regenerative capacity due to excessive and progressive degeneration that occurs in muscular dystrophies than to an inherent defect in SC function itself [150].

By testing the effects of irradiation and myotoxins in the engraftment of donor SCs in nude $D m d^{m d x}$ mouse it was found that when the host SC pool is still preserved, the engraftment is poor; in contrast, when the host SC pool 
is incapacitated by irradiation, but the stem cell niche is preserved, the donor cell is able to repopulate and regenerate the muscle [151]. Boldrin et al. investigated the regenerative potential of SCs isolated from young and old $D m d^{m d x}$ mice. They found that both young and aged SCs are able to regenerate the muscle of preirradiated young nude $D m d^{m d x}$, reinforcing the notion that the SC function is preserved and that the dystrophic environment, instead of an inherent defect, influences it negatively [152]. The main message of these works is that for future cell therapies it will be interesting to capacitate the host stem cell pool, as well as the preservation/amelioration of a functional niche, to obtain successful results.

An important study performed in several animal models also gave an insight into how the satellite cells are regulated in a context of muscular dystrophies [153]. In the SJL/L mouse model for the limb-girdle muscular dystrophy type $2 \mathrm{~B}$ the levels of $M y o D$ and $M y f 5$ were found to be downregulated, which indicates that in this animal the satellite cells remain quiescent, which is expected since the histopathology of this animal shows no evidence of the degeneration and regeneration process. This same downregulation was found in the animal Large $e^{m y d}$, which is consistent with previous results that shows that the mutation in this animal could interfere with the satellite cell functioning and self-renewal [149]. On the other hand, the animal models $D m d^{m d x}$ and Lama $2^{d y-2 J} / J$, the models for congenital muscular dystrophy type $1 \mathrm{~A}$, showed enhanced expression levels of $M y o D$ and Myf5, indicating that in these models the satellite cells are activated, which is consistent with the presence of regeneration areas in their histology.

\section{Therapies}

Since the identification of stem cells, the most promising therapy for muscle wasting diseases has been the cell therapy. The first myoblast transplantation was done in the late 1970 s when it was shown that donor myoblasts were able to fuse within host myofibers [154]. One decade later, the demonstration that donor myoblasts restored dystrophin expression in $D m d^{m d x}$ myofibers [155] opened the precedent for many human clinical trials [156-163]; nevertheless, the results were not satisfactory, mainly by the reduced regenerative potential of myoblasts, once they are more committed and differentiated in comparison to SCs.

Entire myofibers can be grafted into host muscle where SCs attached to donor myofibers contribute to muscle regeneration [46]. The advantages of myofiber transplant are as follows: a maximal engraftment is required, a minimal number of cells are required, and the cells are transplanted together with their niche, although these are not easy to apply in clinics [164].

SCs isolated by flow cytometry were transplanted in $D m d^{m d x}$ mice and it was seen that they engrafted into their muscles and also contributed to the SC compartment, but if the cells were cultured before transplantation, their regenerative potential was reduced [165]. The transplantation of a single luciferase-expressing SC helped to verify the fact that it can self-renew and differentiate, demonstrating the relevance of a careful selection of which cell to use given the high population heterogeneity [166]. Taken together, the studies about direct isolation and transplantation of SCs show the advantages of the requirement of a low number of cells, efficient engraftment, and the repopulation of the host niche with new SCs; in contrast, the migration of transplanted cells is limited, only a small number of cells are isolated, and they cannot be maintained for a long time in vitro [164].

Therefore, the use of progenitor cells like SCs is more promising with the advantage of also replenishing the stem cell pool with the possibility of a sustained response. However, the use of these cells in therapy is still not a reality and many challenges remain to be overcome. These include selection of the most suitable subpopulation, optimal culture conditions, and modulation of signaling pathways that control quiescence and self-renewal and delivery of the cells. The choice between systemic and local injections must consider specific features of each disease, like disease severity and the number and size of affected muscles. Still, both strategies have their limitations and issues including homing, engraftment, and long-term survival. Thus, given all the aspects to be dealt and the divergence between in vitro and in vivo results, the combination of different strategies would be more promising.

\section{Conclusion}

Satellite cells are the first in line for muscle regeneration, and so they are the most promising target in a cell-based therapy for muscle wasting disorders. As shown throughout this review, they have numerous advantages such as easy identification, self-renewal, and myogenic differentiation, which is well understood, and they have been already tested in a therapeutic context. Nevertheless, many questions remain to be answered and this review aimed to explore some possible aspects that could be considered in order to achieve an efficient cell therapy.

At first, the heterogeneity of this population should be considered, such as choosing the ones with better capacity of self-renewal to replenish the pool in an injured muscle or the ones that could be more prone to differentiation. Additionally, since SCs from different muscles or fibers can be distinct, it is important to consider these aspects in order to treat a specific muscle group, for example. The quiescence and activation process is also an aspect that should be considered, since it can be regulated and used, for instance, to direct activation of resident cells. Finally, with previous studies regarding muscular dystrophies and therapies, it is possible to learn about ideal culture conditions and better ways to deliver cells, for example.

It is important to notice that an issue regarding nomenclature of different types of satellite cells may complicate the data interpretation and comparison across studies, since different terms are sometimes used by authors for the same type of cells, or different cells are referred to them with the same general nomenclature. It is possible, therefore, that authors are dealing with the same entities but naming them differently. Hence, it would be valuable if the scientific 
community found a consensus concerning the diversity of the various cell populations studied.

Major hurdles still have to be dealt with, such as the wide distribution of skeletal muscles within the body and the effect of genetic defects in resident cells; however, this review proposes that the knowledge of the satellite cells basic biology may help in the development of further cell-based therapies.

\section{Conflict of Interests}

The authors declare that there is no conflict of interests regarding the publication of this paper.

\section{Authors' Contribution}

Camila F. Almeida and Stephanie A. Fernandes contributed equally to this work.

\section{Acknowledgments}

This work was supported by Fundação de Amparo a Pesquisa do Estado de São Paulo-Centro de Pesquisa, Inovação e Difusão (FAPESP-CEPID), Conselho Nacional de Desenvolvimento Científico e Tecnológico (CNPq-INCT), Financiadora de Estudos e Projetos (FINEP), and Coordenação de Aperfeiçoamento de Pessoal de Nível Superior-Comitê Francês de Avaliação da Cooperação Universitária com o Brasil (CAPES-COFECUB).

\section{References}

[1] S. B. P. Chargé and M. A. Rudnicki, "Cellular and molecular regulation of muscle regeneration," Physiological Reviews, vol. 84, no. 1, pp. 209-238, 2004.

[2] D. B. Allbrook, M. F. Han, and A. E. Hellmuth, "Population of muscle satellite cells in relation to age and mitotic activity," Pathology, vol. 3, no. 3, pp. 223-243, 1971.

[3] R. Bischoff and C. Heintz, "Enhancement of skeletal muscle regeneration," Developmental Dynamics, vol. 201, no. 1, pp. 4154, 1994.

[4] A. Mauro, "Satellite cell of skeletal muscle fibers," Journal of Biophysical and Biochemical Cytology, vol. 9, pp. 493-495, 1961.

[5] P. Seale, L. A. Sabourin, A. Girgis-Gabardo, A. Mansouri, P. Gruss, and M. A. Rudnicki, "Pax7 is required for the specification of myogenic satellite cells," Cell, vol. 102, no. 6, pp. 777-786, 2000.

[6] S. Biressi and T. A. Rando, "Heterogeneity in the muscle satellite cell population," Seminars in Cell and Developmental Biology, vol. 21, no. 8, pp. 845-854, 2010.

[7] A. J. Wagers and I. M. Conboy, "Cellular and molecular signatures of muscle regeneration: current concepts and controversies in adult myogenesis," Cell, vol. 122, no. 5, pp. 659-667, 2005.

[8] T. H. Cheung and T. A. Rando, "Molecular regulation of stem cell quiescence," Nature Reviews Molecular Cell Biology, vol. 14, no. 6, pp. 329-340, 2013.

[9] S. Kuang and M. A. Rudnicki, "The emerging biology of satellite cells and their therapeutic potential," Trends in Molecular Medicine, vol. 14, no. 2, pp. 82-91, 2008.
[10] L. Heslop, J. E. Morgan, and T. A. Partridge, "Evidence for a myogenic stem cell that is exhausted in dystrophic muscle," Journal of Cell Science, vol. 113, part 12, pp. 2299-2308, 2000.

[11] C. F. Bentzinger, Y. X. Wang, and M. A. Rudnicki, "Building muscle: molecular regulation of myogenesis," Cold Spring Harbor Perspectives in Biology, vol. 4, no. 2, 2012.

[12] M. H. Parker, P. Seale, and M. A. Rudnicki, "Looking back to the embryo: defining transcriptional networks in adult myogenesis," Nature Reviews Genetics, vol. 4, no. 7, pp. 497-507, 2003.

[13] R. Sambasivan and S. Tajbakhsh, "Skeletal muscle stem cell birth and properties," Seminars in Cell and Developmental Biology, vol. 18, no. 6, pp. 870-882, 2007.

[14] T. A. Davis and M. L. Fiorotto, "Regulation of muscle growth in neonates," Current Opinion in Clinical Nutrition and Metabolic Care, vol. 12, no. 1, pp. 78-85, 2009.

[15] A. Aulehla and O. Pourquié, "Signaling gradients during paraxial mesoderm development," Cold Spring Harbor Perspectives in Biology, vol. 2, no. 2, Article ID a000869, 2010.

[16] B. Jostes, C. Walther, and P. Gruss, “The murine paired box gene, Pax7, is expressed specifically during the development of the nervous and muscular system," Mechanisms of Development, vol. 33, no. 1, pp. 27-37, 1990.

[17] M. D. Goulding, G. Chalepakis, U. Deutsch, J. R. Erselius, and P. Gruss, "Pax-3, a novel murine DNA binding protein expressed during early neurogenesis," The EMBO Journal, vol. 10, no. 5, pp. $1135-1147,1991$.

[18] J. C. Kiefer and S. D. Hauschka, "Myf-5 is transiently expressed in nonmuscle mesoderm and exhibits dynamic regional changes within the presegmented mesoderm and somites I-IV," Developmental Biology, vol. 232, no. 1, pp. 77-90, 2001.

[19] D. Sassoon, G. Lyons, W. E. Wright et al., "Expression of two myogenic regulatory factors myogenin and $\mathrm{MyoDl}$ during mouse embryogenesis," Nature, vol. 341, no. 6240, pp. 303-307, 1989.

[20] Y. Cinnamon, N. Kahane, I. Bachelet, and C. Kalcheim, "The sub-lip domain-a distinct pathway for myotome precursors that demonstrate rostral-caudal migration," Development, vol. 128, no. 3, pp. 341-351, 2001.

[21] F. Relaix, D. Rocancourt, A. Mansouri, and M. Buckingham, "A Pax3/Pax7-dependent population of skeletal muscle progenitor cells," Nature, vol. 435, no. 7044, pp. 948-953, 2005.

[22] J. Schienda, K. A. Engleka, S. Jun et al., "Somitic origin of limb muscle satellite and side population cells," Proceedings of the National Academy of Sciences of the United States of America, vol. 103, no. 4, pp. 945-950, 2006.

[23] J. Gros, M. Manceau, V. Thomé, and C. Marcelle, "A common somitic origin for embryonic muscle progenitors and satellite cells," Nature, vol. 435, no. 7044, pp. 954-958, 2005.

[24] L. Kassar-Duchossoy, E. Giacone, B. Gayraud-Morel, A. Jory, D. Gomès, and S. Tajbakhsh, "Pax3/Pax7 mark a novel population of primitive myogenic cells during development," Genes and Development, vol. 19, no. 12, pp. 1426-1431, 2005.

[25] C. Lepper and C.-M. Fan, "Inducible lineage tracing of Pax7descendant cells reveals embryonic origin of adult satellite cells," Genesis, vol. 48, no. 7, pp. 424-436, 2010.

[26] M. A. Rudnicki, F. Le Grand, I. McKinnell, and S. Kuang, “The molecular regulation of muscle stem cell function," Cold Spring Harbor Symposia on Quantitative Biology, vol. 73, pp. 323-331, 2008 . 
[27] S. Ciciliot and S. Schiaffino, "Regeneration of mammalian skeletal muscle. Basic mechanisms and clinical implications," Current Pharmaceutical Design, vol. 16, no. 8, pp. 906-914, 2010.

[28] C. Lepper, T. A. Partridge, and C.-M. Fan, "An absolute requirement for Pax7-positive satellite cells in acute injuryinduced skeletal muscle regeneration," Development, vol. 138, no. 17, pp. 3639-3646, 2011.

[29] H. C. Olguin and B. B. Olwin, "Pax-7 up-regulation inhibits myogenesis and cell cycle progression in satellite cells: a potential mechanism for self-renewal," Developmental Biology, vol. 275, no. 2, pp. 375-388, 2004.

[30] M. Buckingham, L. Bajard, T. Chang et al., "The formation of skeletal muscle: from somite to limb," Journal of Anatomy, vol. 202, no. 1, pp. 59-68, 2003.

[31] D. D. W. Cornelison and B. J. Wold, "Single-cell analysis of regulatory gene expression in quiescent and activated mouse skeletal muscle satellite cells," Developmental Biology, vol. 191, no. 2, pp. 270-283, 1997.

[32] F. Relaix, D. Montarras, S. Zaffran et al., "Pax3 and Pax7 have distinct and overlapping functions in adult muscle progenitor cells," The Journal of Cell Biology, vol. 172, no. 1, pp. 91-102, 2006.

[33] S. Oustanina, G. Hause, and T. Braun, "Pax7 directs postnatal renewal and propagation of myogenic satellite cells but not their specification," The EMBO Journal, vol. 23, no. 16, pp. 3430-3439, 2004.

[34] J. R. Beauchamp, L. Heslop, D. S. W. Yu et al., "Expression of CD34 and Myf5 defines the majority of quiescent adult skeletal muscle satellite cells," Journal of Cell Biology, vol. 151, no. 6, pp. 1221-1234, 2000.

[35] R. Meech, K. N. Gonzalez, M. Barro et al., "Barx2 is expressed in satellite cells and is required for normal muscle growth and regeneration," STEM CELLS, vol. 30, no. 2, pp. 253-265, 2012.

[36] A. Irintchev, M. Zeschnigk, A. Starzinski-Powitz, and A. Wernig, "Expression pattern of M-cadherin in normal, denervated, and regenerating mouse muscles," Developmental Dynamics, vol. 199, no. 4, pp. 326-337, 1994.

[37] D. J. Burkin and S. J. Kaufman, "The $\alpha 7 \beta 1$ integrin in muscle development and disease," Cell and Tissue Research, vol. 296, no. 1, pp. 183-190, 1999.

[38] V. F. Gnocchi, R. B. White, Y. Ono, J. A. Ellis, and P. S. Zammit, "Further characterisation of the molecular signature of quiescent and activated mouse muscle satellite cells," PLoS ONE, vol. 4, no. 4, Article ID e5205, 2009.

[39] D. D. W. Cornelison, M. S. Filla, H. M. Stanley, A. C. Rapraeger, and B. B. Olwin, "Syndecan-3 and syndecan-4 specifically mark skeletal muscle satellite cells and are implicated in satellite cell maintenance and muscle regeneration," Developmental Biology, vol. 239, no. 1, pp. 79-94, 2001.

[40] M. Z. Ratajczak, M. Majka, M. Kucia et al., "Expression of functional CXCR4 by muscle satellite cells and secretion of SDF-1 by muscle-derived fibroblasts is associated with the presence of both muscle progenitors in bone marrow and hematopoietic stem/progenitor cells in muscles," Stem Cells, vol. 21, no. 3, pp. 363-371, 2003.

[41] D. Volonte, Y. Liu, and F. Galbiati, “The modulation of caveolin1 expression controls satellite cell activation during muscle repair," The FASEB Journal, vol. 19, no. 2, pp. 237-239, 2005.

[42] S.-I. Fukada, A. Uezumi, M. Ikemoto et al., "Molecular signature of quiescent satellite cells in adult skeletal muscle," Stem Cells, vol. 25, no. 10, pp. 2448-2459, 2007.
[43] G. D. Rosen, J. R. Sanes, R. LaChance, J. M. Cunningham, J. Roman, and D. C. Dean, "Roles for the integrin VLA-4 and its counter receptor VCAM-1 in myogenesis," Cell, vol. 69, no. 7, pp. 1107-1119, 1992.

[44] N. A. Dumont, Y. X. Wang, and M. A. Rudnicki, "Intrinsic and extrinsic mechanisms regulating satellite cell function," Development, vol. 142, no. 9, pp. 1572-1581, 2015.

[45] H. Yin, F. Price, and M. A. Rudnicki, "Satellite cells and the muscle stem cell niche," Physiological Reviews, vol. 93, no. 1, pp. 23-67, 2013.

[46] C. A. Collins, I. Olsen, P. S. Zammit et al., "Stem cell function, self-renewal, and behavioral heterogeneity of cells from the adult muscle satellite cell niche," Cell, vol. 122, no. 2, pp. 289301, 2005.

[47] P. S. Zammit, "All muscle satellite cells are equal, but are some more equal than others?" Journal of Cell Science, vol. 121, no. 18, pp. 2975-2982, 2008.

[48] S. Kuang, K. Kuroda, F. Le Grand, and M. A. Rudnicki, "Asymmetric self-renewal and commitment of satellite stem cells in muscle," Cell, vol. 129, no. 5, pp. 999-1010, 2007.

[49] P. Rocheteau, B. Gayraud-Morel, I. Siegl-Cachedenier, M. A. Blasco, and S. Tajbakhsh, "A subpopulation of adult skeletal muscle stem cells retains all template DNA strands after cell division," Cell, vol. 148, no. 1-2, pp. 112-125, 2012.

[50] J. V. Chakkalakal, J. Christensen, W. Xiang et al., "Early forming label-retaining muscle stem cells require p27kip1 for maintenance of the primitive state," Development, vol. 141, no. 8, pp. 1649-1659, 2014.

[51] E. Schultz, "Satellite cell proliferative compartments in growing skeletal muscles," Developmental Biology, vol. 175, no. 1, pp. 8494, 1996

[52] Y. Ono, S. Masuda, H.-S. Nam, R. Benezra, Y. Miyagoe-Suzuki, and S. Takeda, "Slow-dividing satellite cells retain long-term self-renewal ability in adult muscle," Journal of Cell Science, vol. 125, no. 5, pp. 1309-1317, 2012.

[53] J. Rantanen, T. Hurme, R. Lukka, J. Heino, and H. Kalimo, "Satellite cell proliferation and the expression of myogenin and desmin in regenerating skeletal muscle: evidence for two different populations of satellite cells," Laboratory Investigation, vol. 72, no. 3, pp. 341-347, 1995.

[54] I. Harel, E. Nathan, L. Tirosh-Finkel et al., "Distinct origins and genetic programs of head muscle satellite cells," Developmental Cell, vol. 16, no. 6, pp. 822-832, 2009.

[55] R. Sambasivan, B. Gayraud-Morel, G. Dumas et al., "Distinct regulatory cascades govern extraocular and pharyngeal arch muscle progenitor cell fates," Developmental Cell, vol. 16, no. 6, pp. 810-821, 2009.

[56] J. D. Porter, S. Israel, B. Gong et al., "Distinctive morphological and gene/protein expression signatures during myogenesis in novel cell lines from extraocular and hindlimb muscle," Physiological Genomics, vol. 24, no. 3, pp. 264-275, 2006.

[57] C. Barjot, M.-L. Cotten, C. Goblet, R. G. Whalen, and F. Bacou, "Expression of myosin heavy chain and of myogenic regulatory factor genes in fast or slow rabbit muscle satellite cell cultures," Journal of Muscle Research and Cell Motility, vol. 16, no. 6, pp. 619-628, 1995.

[58] J. L. Feldman and F. E. Stockdale, "Skeletal muscle satellite cell diversity: satellite cells form fibers of different types in cell culture," Developmental Biology, vol. 143, no. 2, pp. 320-334, 1991. 
[59] C. Lagord, L. Soulet, S. Bonavaud et al., "Differential myogenicity of satellite cells isolated from extensor digitorum longus (EDL) and soleus rat muscles revealed in vitro," Cell and Tissue Research, vol. 291, no. 3, pp. 455-468, 1998.

[60] S. M. Hughes and H. M. Blau, "Muscle fiber pattern is independent of cell lineage in postnatal rodent development," Cell, vol. 68, no. 4, pp. 659-671, 1992.

[61] T. Soukup, I. Jirmanová, K. Mrácková, G. Zachařová, and L.-E. Thornell, "Expression of myosin heavy chain (MyHC) isoforms in rat intrafusal muscle fibres after neonatal deefferentation and subsequent denervation," General Physiology and Biophysics, vol. 18, supplement 1, pp. 81-83, 1999.

[62] T. Soukup and L.-E. Thornell, "Expression of myosin heavy chain isoforms in regenerated muscle spindle fibres after muscle grafting in young and adult rats-plasticity of intrafusal satellite cells," Differentiation, vol. 62, no. 4, pp. 179-186, 1998.

[63] N. Hashimoto, T. Murase, S. Kondo, A. Okuda, and M. Inagawa-Ogashiwa, "Muscle reconstitution by muscle satellite cell descendants with stem cell-like properties," Development, vol. 131, no. 21, pp. 5481-5490, 2004.

[64] A. Neal, L. Boldrin, and J. E. Morgan, "The satellite cell in male and female, developing and adult mouse muscle: distinct stem cells for growth and regeneration," PLoS ONE, vol. 7, no. 5, Article ID e37950, 2012.

[65] S. D. Gopinath and T. A. Rando, "Stem cell review series: aging of the skeletal muscle stem cell niche," Aging Cell, vol. 7, no. 4, pp. 590-598, 2008.

[66] J. V. Chakkalakal, K. M. Jones, M. A. Basson, and A. S. Brack, "The aged niche disrupts muscle stem cell quiescence," Nature, vol. 490, no. 7420, pp. 355-360, 2012.

[67] I. H. Conboy, M. J. Conboy, G. M. Smythe, and T. A. Rando, "Notch-mediated restoration of regenerative potential to aged muscle," Science, vol. 302, no. 5650, pp. 1575-1577, 2003.

[68] C. Mozzetta, S. Consalvi, V. Saccone et al., "Fibroadipogenic progenitors mediate the ability of HDAC inhibitors to promote regeneration in dystrophic muscles of young, but not old Mdx mice," EMBO Molecular Medicine, vol. 5, no. 4, pp. 626-639, 2013.

[69] A. S. Brack, M. J. Conboy, S. Roy et al., "Increased Wnt signaling during aging alters muscle stem cell fate and increases fibrosis," Science, vol. 317, no. 5839, pp. 807-810, 2007.

[70] P. Sousa-Victor, S. Gutarra, L. García-Prat et al., "Geriatric muscle stem cells switch reversible quiescence into senescence," Nature, vol. 506, no. 7488, pp. 316-321, 2014.

[71] J. D. Bernet, J. D. Doles, J. K. Hall, K. Kelly Tanaka, T. A. Carter, and B. B. Olwin, "P38 MAPK signaling underlies a cellautonomous loss of stem cell self-renewal in skeletal muscle of aged mice," Nature Medicine, vol. 20, no. 3, pp. 265-271, 2014.

[72] B. D. Cosgrove, P. M. Gilbert, E. Porpiglia et al., "Rejuvenation of the muscle stem cell population restores strength to injured aged muscles," Nature Medicine, vol. 20, no. 3, pp. 255-264, 2014.

[73] I. M. Conboy, M. J. Conboy, A. J. Wagers, E. R. Girma, I. L. Weismann, and T. A. Rando, "Rejuvenation of aged progenitor cells by exposure to a young systemic environment," Nature, vol. 433, no. 7027, pp. 760-764, 2005.

[74] Z. Qu-Petersen, B. Deasy, R. Jankowski et al., "Identification of a novel population of muscle stem cells in mice: potential for muscle regeneration," Journal of Cell Biology, vol. 157, no. 5, pp. 851-864, 2002.

[75] A. Lu, J. H. Cummins, J. B. Pollett et al., "Isolation of myogenic progenitor populations from Pax7-deficient skeletal muscle based on adhesion characteristics," Gene Therapy, vol. 15, no. 15, pp. 1116-1125, 2008.

[76] N. J. Turner and S. F. Badylak, "Regeneration of skeletal muscle," Cell and Tissue Research, vol. 347, no. 3, pp. 759-774, 2012.

[77] S. Corti, S. Strazzer, R. Del Bo et al., "A subpopulation of murine bone marrow cells fully differentiates along the myogenic pathway and participates in muscle repair in the mdx dystrophic mouse," Experimental Cell Research, vol. 277, no. 1, pp. 74-85, 2002.

[78] J.-H. Lee, P. A. Kosinski, and D. M. Kemp, "Contribution of human bone marrow stem cells to individual skeletal myotubes followed by myogenic gene activation," Experimental Cell Research, vol. 307, no. 1, pp. 174-182, 2005.

[79] P. Bossolasco, S. Corti, S. Strazzer et al., "Skeletal muscle differentiation potential of human adult bone marrow cells," Experimental Cell Research, vol. 295, no. 1, pp. 66-78, 2004.

[80] G. Ferrari, G. Cusella-De Angelis, M. Coletta et al., "Muscle regeneration by bone marrow-derived myogenic progenitors," Science, vol. 279, no. 5356, pp. 1528-1530, 1998.

[81] A. S. de la Garza-Rodea, I. van der Velde, H. Boersma et al., "Long-term contribution of human bone marrow mesenchymal stromal cells to skeletal muscle regeneration in mice," Cell Transplantation, vol. 20, no. 2, pp. 217-231, 2011.

[82] Y. Liu, X. Yan, Z. Sun et al., "Flk-1+ adipose-derived mesenchymal stem cells differentiate into skeletal muscle satellite cells and ameliorate muscular dystrophy in MDX Mice," Stem Cells and Development, vol. 16, no. 5, pp. 695-706, 2007.

[83] A.-M. Rodriguez, D. Pisani, C. A. Dechesne et al., "Transplantation of a multipotent cell population from human adipose tissue induces dystrophin expression in the immunocompetent $\mathrm{mdx}$ mouse," Journal of Experimental Medicine, vol. 201, no. 9, pp. 1397-1405, 2005.

[84] A. S. de la Garza-Rodea, I. van der Velde-van Dijke, H. Boersma et al., "Myogenic properties of human mesenchymal stem cells derived from three different sources," Cell Transplantation, vol. 21, no. 1, pp. 153-173, 2012.

[85] J. Meng, S. Chun, R. Asfahani, H. Lochmüller, F. Muntoni, and J. Morgan, "Human skeletal muscle-derived CD133 ${ }^{+}$cells form functional satellite cells after intramuscular transplantation in immunodeficient host mice," Molecular Therapy, vol. 22, no. 5, pp. 1008-1017, 2014.

[86] E. Negroni, I. Riederer, S. Chaouch et al., "In vivo myogenic potential of human $\mathrm{CD} 33^{+}$muscle-derived stem cells: a quantitative study," Molecular Therapy, vol. 17, no. 10, pp. 1771-1778, 2009.

[87] Y. Torrente, M. Belicchi, C. Marchesi et al., "Autologous transplantation of muscle-derived CD $133^{+}$stem cells in Duchenne muscle patients," Cell Transplantation, vol. 16, no. 6, pp. 563577, 2007.

[88] A. Dellavalle, M. Sampaolesi, R. Tonlorenzi et al., "Pericytes of human skeletal muscle are myogenic precursors distinct from satellite cells," Nature Cell Biology, vol. 9, no. 3, pp. 255-267, 2007.

[89] M. Sampaolesi, S. Blot, G. D’Antona et al., "Mesoangioblast stem cells ameliorate muscle function in dystrophic dogs," Nature, vol. 444, no. 7119, pp. 574-579, 2006.

[90] K. K. Tanaka, J. K. Hall, A. A. Troy, D. D. W. Cornelison, S. M. Majka, and B. B. Olwin, "Syndecan-4-expressing muscle progenitor cells in the SP engraft as satellite cells during muscle regeneration," Cell Stem Cell, vol. 4, no. 3, pp. 217-225, 2009.

[91] K. R. Muskiewicz, N. Y. Frank, A. F. Flint, and E. Gussoni, "Myogenic potential of muscle side and main population cells 
after intravenous injection into sub-lethally irradiated $\mathrm{mdx}$ mice," Journal of Histochemistry and Cytochemistry, vol. 53, no. 7, pp. 861-873, 2005.

[92] D. Shi, H. Reinecke, C. E. Murry, and B. Torok-Storb, "Myogenic fusion of human bone marrow stromal cells, but not hematopoietic cells," Blood, vol. 104, no. 1, pp. 290-294, 2004.

[93] N. M. Vieira, V. Brandalise, E. Zucconi et al., "Human multipotent adipose-derived stem cells restore dystrophin expression of Duchenne skeletal-muscle cells in vitro," Biology of the Cell, vol. 100, no. 4, pp. 231-241, 2008.

[94] F. D. Camargo, R. Green, Y. Capetanaki et al., "Single hematopoietic stem cells generate skeletal muscle through myeloid intermediates," Nature Medicine, vol. 9, pp. 1520-1527, 2003.

[95] M. A. LaBarge and H. M. Blau, "Biological progression from adult bone marrow to mononucleate muscle stem cell to multinucleate muscle fiber in response to injury," Cell, vol. 111, no. 4, pp. 589-601, 2002.

[96] S. Y. Corbel, A. Lee, L. Yi et al., "Contribution of hematopoietic stem cells to skeletal muscle," Nature Medicine, vol. 9, no. 12, pp. 1528-1532, 2003.

[97] E. S. Luth, S. J. Jun, M. K. Wessen, K. Liadaki, E. Gussoni, and L. M. Kunkel, "Bone marrow side population cells are enriched for progenitors capable of myogenic differentiation," Journal of Cell Science, vol. 121, no. 9, pp. 1426-1434, 2008.

[98] A. W. B. Joe, L. Yi, A. Natarajan et al., "Muscle injury activates resident fibro/adipogenic progenitors that facilitate myogenesis," Nature Cell Biology, vol. 12, no. 2, pp. 153-163, 2010.

[99] J. E. Heredia, L. Mukundan, F. M. Chen et al., "Type 2 innate signals stimulate fibro/adipogenic progenitors to facilitate muscle regeneration," Cell, vol. 153, no. 2, pp. 376-388, 2013.

[100] J. Farup, L. Madaro, P. L. Puri, and U. R. Mikkelsen, "Interactions between muscle stem cells, mesenchymal-derived cells and immune cells in muscle homeostasis, regeneration and disease," Cell Death and Disease, vol. 6, no. 7, Article ID e1830, 2015.

[101] A. Asakura, M. Komaki, and M. A. Rudnicki, "Muscle satellite cells are multipotential stem cells that exhibit myogenic, osteogenic, and adipogenic differentiation," Differentiation, vol. 68, no. 4-5, pp. 245-253, 2001.

[102] M. R. Wada, M. Inagawa-Ogashiwa, S. Shimizu, S. Yasumoto, and N. Hashimoto, "Generation of different fates from multipotent muscle stem cells," Development, vol. 129, no. 12, pp. 29872995, 2002.

[103] M. Csete, J. Walikonis, N. Slawny et al., "Oxygen-mediated regulation of skeletal muscle satellite cell proliferation and adipogenesis in culture," Journal of Cellular Physiology, vol. 189, no. 2, pp. 189-196, 2001.

[104] G. Shefer, M. Wleklinski-Lee, and Z. Yablonka-Reuveni, "Skeletal muscle satellite cells can spontaneously enter an alternative mesenchymal pathway," Journal of Cell Science, vol. 117, no. 22, pp. 5393-5404, 2004.

[105] C. A. Rossi, M. Pozzobon, A. Ditadi et al., "Clonal characterization of rat muscle satellite cells: proliferation, metabolism and differentiation define an intrinsic heterogeneity," PLOS ONE, vol. 5, no. 1, Article ID e8523, 2010.

[106] D. F. Pisani, C. A. Dechesne, S. Sacconi et al., "Isolation of a highly myogenic CD34-negative subset of human skeletal muscle cells free of adipogenic potential," STEM CELLS, vol. 28, no. 4, pp. 753-764, 2010.
[107] I. M. Conboy and T. A. Rando, “The regulation of Notch signaling controls satellite cell activation and cell fate determination in postnatal myogenesis," Developmental Cell, vol. 3, no. 3, pp. 397-409, 2002.

[108] C. R. R. Bjornson, T. H. Cheung, L. Liu, P. V. Tripathi, K. M. Steeper, and T. A. Rando, "Notch signaling is necessary to maintain quiescence in adult muscle stem cells," Stem Cells, vol. 30, no. 2, pp. 232-242, 2012.

[109] M. F. Buas and T. Kadesch, "Regulation of skeletal myogenesis by Notch," Experimental Cell Research, vol. 316, no. 18, pp. 30283033, 2010.

[110] M. Philippos, R. Sambasivan, D. Castel, P. Rocheteau, V. Bizzarro, and S. Tajbakhsh, "A critical requirement for notch signaling in maintenance of the quiescent skeletal muscle stem cell state," Stem Cells, vol. 30, no. 2, pp. 243-252, 2012.

[111] C. Jiang, Y. Wen, K. Kuroda, K. Hannon, M. A. Rudnicki, and S. Kuang, "Notch signaling deficiency underlies age-dependent depletion of satellite cells in muscular dystrophy," DMM Disease Models and Mechanisms, vol. 7, no. 8, pp. 997-1004, 2014.

[112] S. D. Gopinath, A. E. Webb, A. Brunet, and T. A. Rando, "FOXO3 promotes quiescence in adult muscle stem cells during the process of self-renewal," Stem Cell Reports, vol. 2, no. 4, pp. 414-426, 2014.

[113] T. H. Cheung, N. L. Quach, G. W. Charville et al., "Maintenance of muscle stem-cell quiescence by microRNA-489," Nature, vol. 482, no. 7386, pp. 524-528, 2012.

[114] C. G. Crist, D. Montarras, and M. Buckingham, "Muscle satellite cells are primed for myogenesis but maintain quiescence with sequestration of Myf5 mRNA targeted by microRNA-31 in mRNP granules," Cell Stem Cell, vol. 11, no. 1, pp. 118-126, 2012.

[115] M. A. Hausburg, J. D. Doles, S. L. Clement et al., "Posttranscriptional regulation of satellite cell quiescence by TTPmediated mRNA decay," eLife, vol. 4, Article ID e03390, 2015.

[116] K. Kondoh, K. Sunadome, and E. Nishida, "Notch signaling suppresses p38 MAPK activity via induction of MKP-1 in myogenesis," The Journal of Biological Chemistry, vol. 282, no. 5, pp. 3058-3065, 2007.

[117] N. C. Jones, K. J. Tyner, L. Nibarger et al., "The p38 $\alpha / \beta$ MAPK functions as a molecular switch to activate the quiescent satellite cell," The Journal of Cell Biology, vol. 169, no. 1, pp. 105-116, 2005.

[118] R. Tatsumi, J. E. Anderson, C. J. Nevoret, O. Halevy, and R. E. Allen, "HGF/SF is present in normal adult skeletal muscle and is capable of activating satellite cells," Developmental Biology, vol. 194, no. 1, pp. 114-128, 1998.

[119] Y.-P. Li, "TNF- $\alpha$ is a mitogen in skeletal muscle," The American Journal of Physiology-Cell Physiology, vol. 285, no. 2, pp. C370C376, 2003.

[120] Z. Yablonka-Reuveni, R. Seger, and A. J. Rivera, "Fibroblast growth factor promotes recruitment of skeletal muscle satellite cells in young and old rats," Journal of Histochemistry and Cytochemistry, vol. 47, no. 1, pp. 23-42, 1999.

[121] N. C. Jones, Y. V. Fedorov, R. S. Rosenthal, and B. B. Olwin, "ERK1/2 is required for myoblast proliferation but is dispensable for muscle gene expression and cell fusion," Journal of Cellular Physiology, vol. 186, no. 1, pp. 104-115, 2001.

[122] E. Perdiguero, V. Ruiz-Bonilla, A. L. Serrano, and P. MuñozCánoves, "Genetic deficiency of p38 $\alpha$ reveals its critical role in myoblast cell cycle exit: the p $38 \alpha$-JNK connection," Cell Cycle, vol. 6, no. 11, pp. 1298-1303, 2007.

[123] M. M. Murphy, A. C. Keefe, J. A. Lawson, S. D. Flygare, M. Yandell, and G. Kardon, "Transiently active wnt $/ \beta$-catenin 
signaling is not required but must be silenced for stem cell function during muscle regeneration," Stem Cell Reports, vol. 3, no. 3, pp. 475-488, 2014.

[124] A. E. Jones, F. D. Price, F. Le Grand et al., "Wnt/ $\beta$-catenin controls follistatin signalling to regulate satellite cell myogenic potential," Skeletal Muscle, vol. 5, article 14, 2015.

[125] Y. Yang, Y. Xu, W. Li et al., "STAT3 induces muscle stem cell differentiation by interaction with myoD," Cytokine, vol. 46, no. 1, pp. 137-141, 2009.

[126] M. T. I. Tierney, T. Aydogdu, D. Sala et al., "STAT3 signaling controls satellite cell expansion and skeletal muscle repair," Nature Medicine, vol. 20, no. 10, pp. 1182-1186, 2014.

[127] F. D. Price, J. von Maltzahn, C. F. Bentzinger et al., "Inhibition of JAK-STAT signaling stimulates adult satellite cell function," Nature Medicine, vol. 20, no. 10, pp. 1174-1181, 2014.

[128] Y. Cao, Z. Zhao, J. Gruszczynska-Biegala, and A. Zolkiewska, "Role of metalloprotease disintegrin ADAM12 in determination of quiescent reserve cells during myogenic differentiation in vitro," Molecular and Cellular Biology, vol. 23, no. 19, pp. 67256738, 2003.

[129] K. V. Pajcini, S. Y. Corbel, J. Sage, J. H. Pomerantz, and H. M. Blau, "Transient inactivation of $\mathrm{Rb}$ and ARF yields regenerative cells from postmitotic mammalian muscle," Cell Stem Cell, vol. 7, no. 2, pp. 198-213, 2010.

[130] K. L. Shea, W. Xiang, V. S. LaPorta et al., "Sproutyl regulates reversible quiescence of a self-renewing adult muscle stem cell pool during regeneration," Cell Stem Cell, vol. 6, no. 2, pp. 117129, 2010.

[131] V. Shinin, B. Gayraud-Morel, D. Gomès, and S. Tajbakhsh, "Asymmetric division and cosegregation of template DNA strands in adult muscle satellite cells," Nature Cell Biology, vol. 8, no. 7, pp. 677-682, 2006.

[132] A. Troy, A. B. Cadwallader, Y. Fedorov, K. Tyner, K. K. Tanaka, and B. B. Olwin, "Coordination of satellite cell activation and self-renewal by par-complex-dependent asymmetric activation of p38 $\alpha / \beta$ MAPK," Cell Stem Cell, vol. 11, no. 4, pp. 541-553, 2012.

[133] W. Liu, Y. Wen, P. Bi et al., "Hypoxia promotes satellite cell selfrenewal and enhances the efficiency of myoblast transplantation," Development, vol. 139, no. 16, pp. 2857-2865, 2012.

[134] S. Yennek, M. Burute, M. Théry, and S. Tajbakhsh, "Cell adhesion geometry regulates non-random DNA segregation and asymmetric cell fates in mouse skeletal muscle stem cells," Cell Reports, vol. 7, no. 4, pp. 961-970, 2014.

[135] G. Q. Wallace and E. M. McNally, "Mechanisms of muscle degeneration, regeneration, and repair in the muscular dystrophies," Annual Review of Physiology, vol. 71, pp. 37-57, 2009.

[136] F. Rahimov and L. M. Kunkel, "The cell biology of disease: cellular and molecular mechanisms underlying muscular dystrophy," Journal of Cell Biology, vol. 201, no. 4, pp. 499-510, 2013.

[137] S. Decary, V. Mouly, C. Ben Hamida, A. Sautet, J. P. Barbet, and G. S. Butler-Browne, "Replicative potential and telomere length in human skeletal muscle: implications for satellite cellmediated gene therapy," Human Gene Therapy, vol. 8, no. 12, pp. 1429-1438, 1997.

[138] S. Decary, C. B. Hamida, V. Mouly, J. P. Barbet, F. Hentati, and G. S. Butler-Browne, "Shorter telomeres in dystrophic muscle consistent with extensive regeneration in young children," Neuromuscular Disorders, vol. 10, no. 2, pp. 113-120, 2000.

[139] T. C. Lund, R. W. Grange, and D. A. Lowe, "Telomere shortening in diaphragm and tibialis anterior muscles of aged mdx mice," Muscle and Nerve, vol. 36, no. 3, pp. 387-390, 2007.
[140] A. Sacco, F. Mourkioti, R. Tran et al., "Short telomeres and stem cell exhaustion model Duchenne muscular dystrophy in mdx/mTR mice," Cell, vol. 143, no. 7, pp. 1059-1071, 2010.

[141] K. Oexle, A. Zwirner, K. Freudenberg, A. Kohlschütter, and A. Speer, "Examination of telomere lengths in muscle tissue casts doubt on replicative aging as cause of progression in Duchenne muscular dystrophy," Pediatric Research, vol. 42, no. 2, pp. 226231, 1997.

[142] C. Delaporte, M. Dehaupas, and M. Fardeau, "Comparison between the growth pattern of cell cultures from normal and Duchenne dystrophy muscle," Journal of the Neurological Sciences, vol. 64, no. 2, pp. 149-160, 1984.

[143] G. Jasmin, C. Tautu, M. Vanasse, P. Brochu, and R. Simoneau, "Impaired muscle differentiation in explant cultures of Duchenne muscular dystrophy," Laboratory Investigation, vol. 50, no. 2, pp. 197-207, 1984.

[144] J. E. Morgan and P. S. Zammit, "Direct effects of the pathogenic mutation on satellite cell function in muscular dystrophy," Experimental Cell Research, vol. 316, no. 18, pp. 3100-3108, 2010.

[145] E. Kudryashova, I. Kramerova, and M. J. Spencer, "Satellite cell senescence underlies myopathy in a mouse model of limb-girdle muscular dystrophy $2 \mathrm{H}$," The Journal of Clinical Investigation, vol. 122, no. 5, pp. 1764-1776, 2012.

[146] S. Lin, H. Shen, B. Jin et al., "Brief report: blockade of Notch signaling in muscle stem cells causes muscular dystrophic phenotype and impaired muscle regeneration," STEM CELLS, vol. 31, no. 4, pp. 823-828, 2013.

[147] N. A. Dumont, Y. X. Wang, J. von Maltzahn et al., "Dystrophin expression in muscle stem cells regulates their polarity and asymmetric division," Nature Medicine, vol. 21, no. 12, pp. 14551463, 2015.

[148] J. Ross, A. Benn, J. Jonuschies et al., "Defects in glycosylation impair satellite stem cell function and niche composition in the muscles of the dystrophic Large ${ }^{\text {myd }}$ mouse," STEM CELLS, vol. 30, no. 10, pp. 2330-2341, 2012.

[149] R. D. Cohn, M. D. Henry, D. E. Michele et al., "Disruption of DAG1 in differentiated skeletal muscle reveals a role for dystroglycan in muscle regeneration," Cell, vol. 110, no. 5, pp. 639-648, 2002.

[150] H. Awano, A. Blaeser, B. Wu, P. Lu, E. Keramaris-Vrantsis, and Q. Lu, "Dystroglycanopathy muscles lacking functional glycosylation of alpha-dystroglycan retain regeneration capacity," Neuromuscular Disorders, vol. 25, no. 6, pp. 474-484, 2015.

[151] L. Boldrin, A. Neal, P. S. Zammit, F. Muntoni, and J. E. Morgan, "Donor satellite cell engraftment is significantly augmented when the host niche is preserved and endogenous satellite cells are incapacitated," Stem Cells, vol. 30, no. 9, pp. 1971-1984, 2012.

[152] L. Boldrin, P. S. Zammit, and J. E. Morgan, "Satellite cells from dystrophic muscle retain regenerative capacity," Stem Cell Research, vol. 14, no. 1, pp. 20-29, 2015.

[153] P. C. G. Onofre-Oliveira, A. L. F. Santos, P. M. Martins, D. Ayub-Guerrieri, and M. Vainzof, "Differential expression of genes involved in the degeneration and regeneration pathways in mouse models for muscular dystrophies," NeuroMolecular Medicine, vol. 14, no. 1, pp. 74-83, 2012.

[154] T. A. Partridge, M. Grounds, and J. C. Sloper, "Evidence of fusion between host and donor myoblasts in skeletal muscle grafts," Nature, vol. 273, no. 5660, pp. 306-308, 1978.

[155] T. A. Partridge, J. E. Morgan, G. R. Coulton, E. P. Hoffman, and L. M. Kunkel, "Conversion of mdx myofibres from dystrophinnegative to -positive by injection of normal myoblasts," Nature, vol. 337, no. 6203, pp. 176-179, 1989. 
[156] E. Gussoni, G. K. Pavlath, A. M. Lanctot et al., "Normal dystrophin transcripts detected in Duchenne muscular dystrophy patients after myoblast transplantation," Nature, vol. 356, no. 6368, pp. 435-438, 1992.

[157] J. Huard, R. Roy, J.-P. Bouchard, F. Malouin, C. L. Richards, and J.-P. Tremblay, "Human myoblast transplantation between immunohistocompatible donors and recipients produces immune reactions," Transplantation Proceedings, vol. 24, no. 6, pp. 3049-3051, 1992.

[158] G. Karpati, D. Ajdukovic, D. Arnold et al., "Myoblast transfer in Duchenne muscular dystrophy," Annals of Neurology, vol. 34, no. 1, pp. 8-17, 1993.

[159] J. P. Tremblay, J. P. Bouchard, F. Malouin et al., "Myoblast transplantation between monozygotic twin girl carriers of Duchenne muscular dystrophy," Neuromuscular Disorders, vol. 3, no. 5-6, pp. 583-592, 1993.

[160] J. P. Tremblay, F. Malouin, R. Roy et al., "Results of a triple blind clinical study of myoblast transplantations without immunosuppressive treatment in young boys with Duchenne muscular dystrophy," Cell Transplantation, vol. 2, no. 2, pp. 99-112, 1993.

[161] J. R. Mendell, J. T. Kissel, A. A. Amato et al., "Myoblast transfer in the treatment of Duchenne's muscular dystrophy," The New England Journal of Medicine, vol. 333, no. 13, pp. 832-838, 1995.

[162] L. Morandi, P. Bernasconi, M. Gebbia et al., "Lack of mRNA and dystrophin expression in DMD patients three months after myoblast transfer," Neuromuscular Disorders, vol. 5, no. 4, pp. 291-295, 1995.

[163] R. G. Miller, K. R. Sharma, G. K. Pavlath et al., "Myoblast implantation in Duchenne muscular dystrophy: the San Francisco study," Muscle \& Nerve, vol. 20, no. 4, pp. 469-478, 1997.

[164] C. F. Bentzinger, Y. X. Wang, J. von Maltzahn, and M. A. Rudnicki, "The emerging biology of muscle stem cells: implications for cell-based therapies," BioEssays, vol. 35, no. 3, pp. 231-241, 2013.

[165] D. Montarras, J. Morgan, C. Colins et al., "Direct isolation of satellite cells for skeletal muscle regeneration," Science, vol. 309, no. 5743, pp. 2064-2067, 2005.

[166] A. Sacco, R. Doyonnas, P. Kraft, S. Vitorovic, and H. M. Blau, "Self-renewal and expansion of single transplanted muscle stem cells," Nature, vol. 456, no. 7221, pp. 502-506, 2008.

[167] M. Cerletti, S. Jurga, C. A. Witczak et al., "Highly efficient, functional engraftment of skeletal muscle stem cells in dystrophic muscles," Cell, vol. 134, no. 1, pp. 37-47, 2008.

[168] M. Marti, N. Montserrat, C. Pardo et al., "M-cadherin-mediated intercellular interactions activate satellite cell division," Journal of Cell Science, vol. 126, no. 22, pp. 5116-5131, 2013.

[169] M. Lindström, A. E. Tjust, and F. Pedrosa Domellöf, "Pax7positive cells/satellite cells in human extraocular muscles," Investigative Opthalmology \& Visual Science, vol. 56, no. 10, pp. 6132-6143, 2015.

[170] L. J. Kirkpatrick, Z. Yablonka-Reuveni, and B. W. C. Rosser, "Retention of Pax3 expression in satellite cells of muscle spindles," Journal of Histochemistry and Cytochemistry, vol. 58, no. 4, pp. 317-327, 2010.

[171] M. Lindström, F. Pedrosa-Domellöf, and L.-E. Thornell, "Satellite cell heterogeneity with respect to expression of MyoD, myogenin, Dlk1 and c-Met in human skeletal muscle: application to a cohort of power lifters and sedentary men," Histochemistry and Cell Biology, vol. 134, no. 4, pp. 371-385, 2010.
[172] S. Günther, J. Kim, S. Kostin, C. Lepper, C.-M. Fan, and T. Braun, "Myf5-positive satellite cells contribute to Pax7dependent long-term maintenance of adult muscle stem cells," Cell Stem Cell, vol. 13, no. 5, pp. 590-601, 2013.

[173] M. Yamaguchi, Y. Watanabe, T. Ohtani et al., "Calcitonin receptor signaling inhibits muscle stem cells from escaping the quiescent state and the niche," Cell Reports, vol. 13, no. 2, pp. 302-314, 2015.

[174] R. L. Frock, B. A. Kudlow, A. M. Evans, S. A. Jameson, S. D. Hauschka, and B. K. Kennedy, "Lamin A/C and emerin are critical for skeletal muscle satellite cell differentiation," Genes and Development, vol. 20, no. 4, pp. 486-500, 2006. 

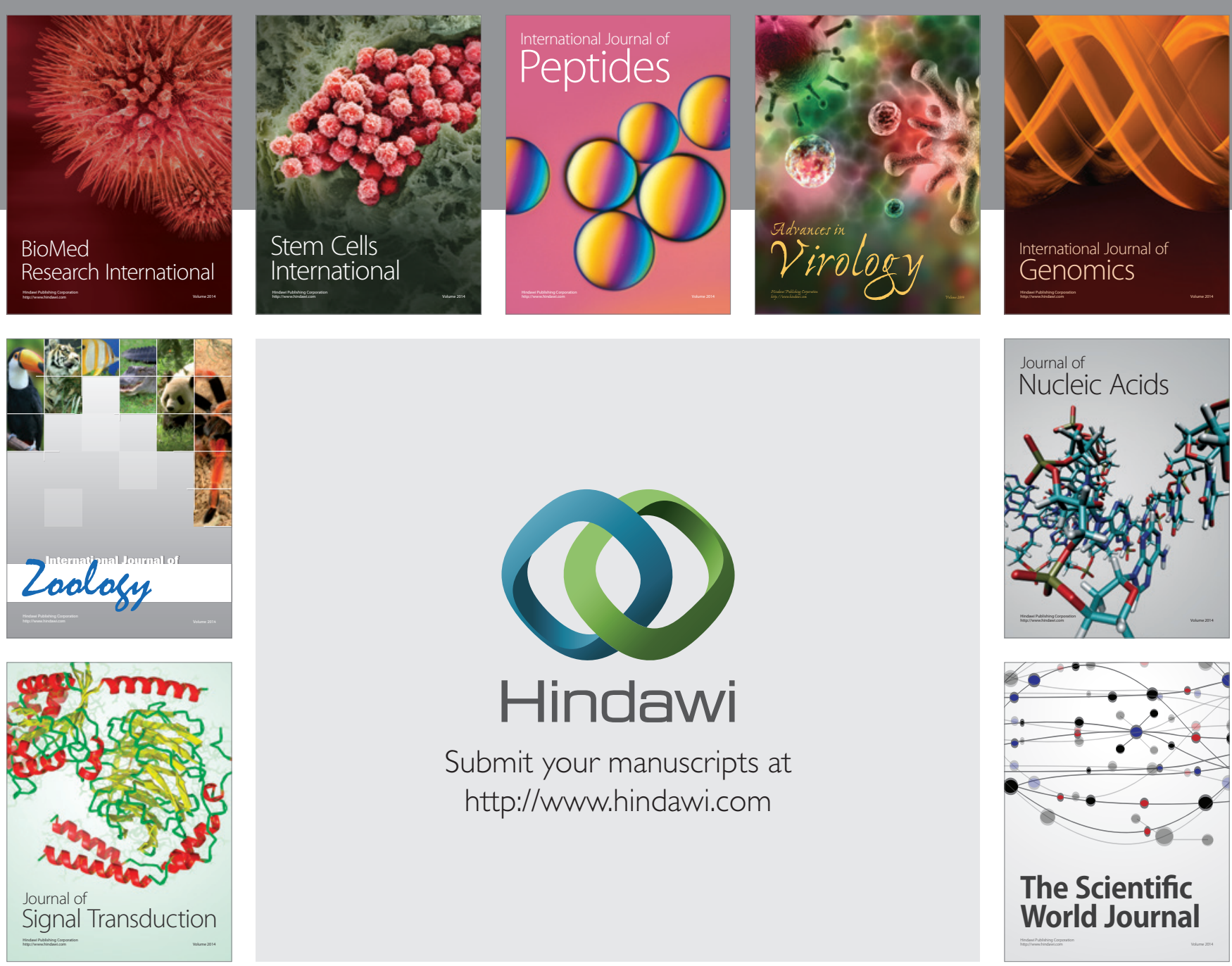

Submit your manuscripts at

http://www.hindawi.com
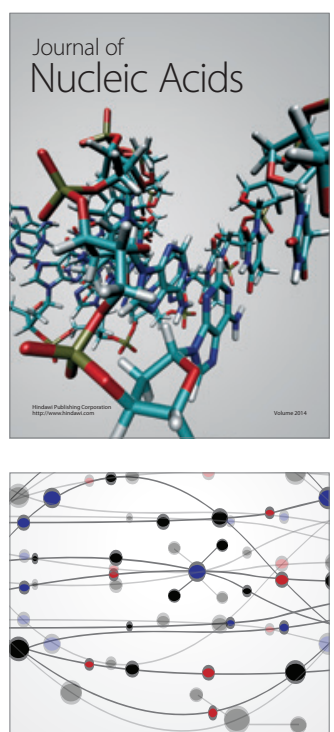

The Scientific World Journal
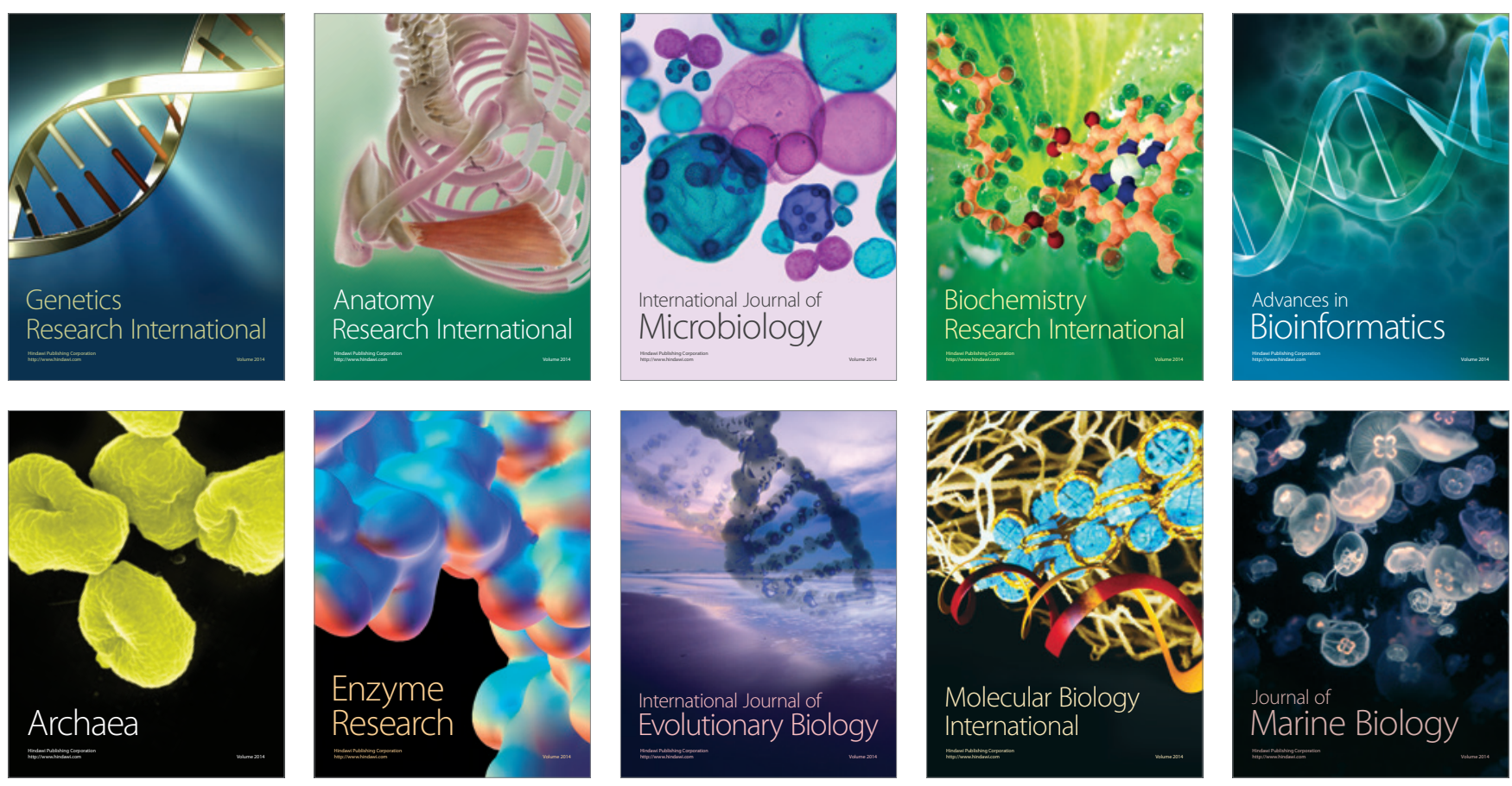